\title{
Analisis Fatwa DSN-MUI No. 43/DSN-MUI/VIII/2004 tentang Ganti Rugi (Ta'widh) terhadap Penerapan Tarif Pembatalan Order di Aplikasi Grab
}

\author{
Meuthia Azzahra*, Eva Misfah Bayuni, Iwan Permana \\ Prodi Hukum Ekonomi Syariah, Fakultas Syariah, Universitas Islam \\ Bandung, Indonesia. \\ *tugasmeuthia@gmail.com , evambayuni@gmail.com, iwanperman4@gmail.com
}

\begin{abstract}
One of many online transportation services which are widely used nowadays is Grab Indonesia. Based on the classification, the practice of online taxi is classified as ijarah amal or wages. In addition to their standard fees, Grab also charged order cancellation fees to its passengers. The fare that should be paid by passengers who cancel their orders is Rp1000 for Grab Bike and Rp3000 for Grab Car services. This regulation has been applied in Lampung and Palembang since June 17, 2019. Based on that, the author is moved to discover the Islamic law perspective on the order cancellation fee applied by Grab. So the title of this research is "The Analysis of Fatwa DSN-MUI No. 43/DSNMUI/VIII/2004 regarding the Order Cancellation Fee on the Grab Application". This is a qualitative research that produces descriptive data. The data was collected using a literature study technique, namely through collecting information from the official Grab Indonesia website, books, papers, and digital news. The collected data is analyzed with interactive analysis techniques that consisted of data reduction, data presentation and conclusion. The result of this study is that the order cancellation fees charged by Grab are generally in line with the provisions of Fatwa DSN-MUI No. 43 of 2004. However, in terms of fee level, Grab charges the fee amount at the beginning of the transaction, which means that the fees charged do not necessarily reflect the actual losses suffered by the driver. The conclusion is that the level of fees charged doesn't comply with the provisions of Fatwa DSN-MUI No. 43 of 2004 .
\end{abstract}

Keywords: fatwa DSN-MUI, order cancellation fee, Grab.

Abstrak. Salah satu dari sekian banyak layanan transportasi online yang paling sering digunakan saat ini adalah Grab Indonesia. Berdasarkan pembagiannya, praktik ojek online ini tergolong dalam ijarah amal alias upah-mengupah. Selain tarif operasional pada umumnya, pihak Grab juga memberikan tarif pembatalan order kepada penumpangnya. Tarif yang harus dibayar oleh penumpang yang membatalkan orderannya yaitu Rp1000 untuk Grab Bike dan Rp3000 untuk layanan Grab Car dan sejenisnya. Kebijakan ini mulai berlaku di kota Lampung dan Palembang sejak tanggal 17 Juni 2019. Berdasarkan hal tersebut, penulis tergerak untuk menganaliss bagaimana pandangan hukum Islam terhadap tarif pembatalan order yang diterapkan Grab. Maka judul dari penelitian ini yaitu "Analisis Fatwa DSN-MUI Nomor 43/DSN-MUI/VIII/2004 tentang Ganti Rugi (Ta'widh) terhadap Penerapan Tarif Pembatalan Order di Aplikasi Grab". Penelitian ini merupakan penelitian kualitatif yang hasilnya berbentuk data-data deskriptif. Teknik pengumpulan data dilakukan dengan metode studi kepustakaan yaitu dengan mengumpulkan informasi dari website resmi Grab Indonesia, bukubuku, karya tulis ilmiah, dan berita-berita elektronik. Data yang sudah terkumpul dianalisis dengan teknik analisis interaktif yang terdiri atas reduksi data, penyajian data, kemudian penarikan kesimpulan. Hasil dari penelitian ini yaitu bahwa kebijakan tarif pembatalan order yang diterapkan Grab sudah sesuai dengan ketentuan Fatwa DSN-MUI Nomor 43 tahun 2004 secara umum. Namun, jika dilihat dari segi besaran tarifnya, Grab menerapkan besaran tarif di awal transaksi, berarti tarif yang dibebankan tersebut belum tentu sama dengan kerugian riil yang dialami oleh pengemudi. Maka dapat disimpulkan bahwa besaran tarif yang dibebankan tersebut tidak sesuai dengan ketentuan Fatwa DSN-MUI No. 43 tahun 2004.

Kata Kunci: fatwa DSN-MUI, tarif pembatalan order, Grab. 


\section{A. Pendahuluan}

Salah satu dari sekian banyak layanan transportasi online yang terkenal adalah Grab Indonesia. Selain tarif operasional pada umumnya, Grab memberikan tarif pembatalan order kepada penumpangnya. Tarif yang harus dibayar oleh penumpang yang membatalkan orderannya yaitu sebesar Rp1000 untuk GrabBike dan Rp3000 untuk layanan GrabCar dan sejenisnya. Kebijakan ini mulai berlaku di kota Lampung dan Palembang sejak tanggal 17 Juni 2019.

Maka menurut kebijakan tersebut, berarti calon penumpang diharuskan membayar tarif pembatalan order untuk mengganti kerugian yang dialami oleh pengemudi. Sehingga dapat dikatakan bahwa pihak Grab dalam hal ini mengambil tarif ganti rugi atas pembatalan yang dilakukan oleh penumpangnya.

Berdasarkan latar belakang tersebut, maka perumusan masalah dari penelitian ini yaitu: "Bagaimana analisis Fatwa DSN-MUI Nomor 43 Tahun 2004 terhadap penerapan tarif pembatalan order di aplikasi Grab?". Selanjutnya, tujuan dalam penelitian ini yaitu untuk mengetahui bagaimana analisis Fatwa DSN-MUI Nomor 43 Tahun 2004 terhadap penerapan tarif pembartalan order di aplikasi Grab.

\section{B. Metodologi Penelitian}

\section{Pendekatan Penelitian}

Penelitian ini menggunakan pendekatan kualitatif, karena data-data yang diolah berbentuk deskriptif seperti informasi mengenai tarif pembatalan order di aplikasi Grab, sehingga tidak perlu melalui prosedur statistik untuk menemukan sebuah kesimpulan.

\section{Jenis Data Penelitian}

Penelitian ini menggunakan jenis data pustaka. Data pustaka yaitu data penelitian yang diperoleh peneliti dari dokumentasi, laporan, buku atau hasil penelitian yang bersifat kepustakaan.

Penelitian ini dapat dikatakan penelitian kepustakaan karena penulis tidak terjun langsung ke lapangan ataupun menyebar angket. Rujukan-rujukan terkait penelitian ini didapat dari literatur-literatur seperti buku, jurnal, dan juga informasi dari website resmi objek penelitian yaitu website resmi Grab Indonesia.

\section{Sumber Data Penelitian}

Sumber data yang digunakan dalam penelitian ini merupakan data sekunder. Data sekunder biasanya berupa catatan, bukti, atau laporan historis yang tersusun dalam arsip (data dokumenter) yang dipublikasikan dan yang tidak dipublikasikan. Dalam penelitian ini data sekunder diperoleh dari lembaga maupun perusahaan atau pihak-pihak yang berhubungan dengan penelitian ini. Data yang ada pada penelitian ini bersumber dari website resmi Grab Indonesia.

\section{Teknik Pengumpulan Data}

Penelitian ini menggunakan teknik dokumentasi berupa informasi mengenai harga produk jasa Grab dan juga penerapan dana pembatalan order yang diterapkan oleh Grab. Data-data tersebut tercantum dalam website resmi Grab Indonesia.

\section{Teknik Analisis Data}

Model atau teknik analisis data pada penelitian ini yaitu teknik analisis interaktif yang dicetuskan oleh Miles dan Huberman. Analisis data model interaktif ini memiliki tiga komponen atau langkah-langkah yang harus dilalui, yaitu: (1) reduksi data, (2) sajian data, dan (3) penarikan kesimpulan/verifikasi.

1. Reduksi data : Pada tahap ini penulis mencari informasi mengenai kebijakan penerapan tarif pembatalan order yang diterapkan oleh Grab, mengaitkannya dengan Fatwa DSNMUI yang membahas mengenai ganti rugi, dan juga mencari sumber atau referensi dari buku-buku, jurnal, skripsi dan literatur lainnya yang membahas mengenai ganti rugi maupun Fatwa DSN-MUI. 
2. Sajian data : Pada tahap ini, penulis mengumpulkan semua data mengenai ganti rugi khususnya menurut Islam, dan menyajikannya dalam bentuk deskriptif di Bab II.

Penarikan kesimpulan : setelah dilakukan analisis, maka dapat dihasilkan kesimpulan berupa analisis kesesuaian antara ketentuan penerapan tarif pembatalan order dengan ketentuan ganti rugi menurut Fatwa DSN-MUI No. 43 tahun 2004.

\section{Hasil Penelitian dan Pembahasan}

Berdasarkan Fatwa DSN-MUI No. 43 Tahun 2004 tentang Ganti Rugi (Ta'widh), ganti rugi boleh dilaksanakan asalkan memenuhi syarat-syarat tertentu. Untuk menganalisis kesesuaian antara kebijakan ganti rugi yang ditetapkan Grab dengan ketentuan ganti rugi yang ditetapkan Fatwa DSN-MUI No. 43 tahun 2004, penulis akan menjabarkannya sesuai poin-poin di bawah ini:

1. "Ganti rugi hanya bisa dikenakan kepada pihak yang melakukan sesuatu yang menyimpang dari ketentuan akad dan menimbulkan kerugian pada pihak lain, baik secara sengaja atau karena kelalaian".

Secara sengaja maupun tidak sengaja, penumpang Grab yang membatalkan order dapat menimbulkan kerugian bagi mitra pengemudi yang bersangkutan. Maka sesuai ketentuan dalam Fatwa DSN-MUI No. 43 Tahun 2004, Grab boleh membebankan tarif ganti rugi untuk menutup kerugian mitra pengemudi.

2. "Kerugian yang dapat dikenakan ganti rugi hanyalah kerugian riil yang dapat diperhitungkan dengan jelas"

"Yang termasuk kerugian riil adalah biaya-biaya riil yang dikeluarkan dalam rangka penagihan hak yang seharusnya dibayarkan".

Kerugian yang dialami oleh mitra pengemudi jika penumpangnya membatalkan order yaitu kerugian materiil dan immateriil. Kerugian materiil yaitu berupa bahan bakar minyak yang terbuang selama perjalanan menuju titik jemput. Kerugian immateriil yaitu waktu yang terbuang sia-sia dan juga kesempatan untuk mendapatkan pesanan dari penumpang lain.

3. "Besar ganti rugi harus sama dengan besar kerugian riil (real loss) yang pasti dialami (fixed cost) dalam transaksi tersebut, bukan kerugian yang diperkirakan akan terjadi di masa depan (potential loss) karena adanya peluang yang hilang (opportunity loss atau alfurshah al-dhai'ah)".

Kerugian bahan bakar minyak yang terbuang merupakan kerugian materiil yang dapat dihitung secara jelas. Sedangkan kerugian imateriil tidak bisa diperhitungkan dengan jelas. Maka sesuai dengan ketentuan Fatwa DSN-MUI No. 43 tersebut, tarif ganti rugi hanya boleh dibebankan untuk kerugian bahan bakar minyak yang terbuang selama perjalanan.

4. "Ganti rugi hanya boleh dikenakan pada transaksi yang menimbulkan utang piutang (dain), seperti salam, istishna' serta murabahah dan ijarah".

Praktik ojek online ini tergolong dalam ijarah amal alias upah-mengupah. Pengendara Grab sebagai pihak yang memberi jasa/tenaga (mu'jir/ajir), penumpang sebagai pengupah (musta'jir), dan jasa transportasi sebagai objek ijarah (manfa'ah). Para pihak melakukan perjanjian melalui aplikasi Grab untuk sebuah perjalanan ke tujuan tertentu dengan tarif yang sudah ditentukan. Setelah perjalanan berakhir, penumpang harus membayar sejumlah tarif yang sudah ditentukan di awal transaksi tadi. Maka sesuai dengan ketentuan Fatwa DSN-MUI No. 43 tahun 2004, ganti rugi yang diterapkan oleh Grab ini boleh dilakukan.

5. "Besar ganti rugi harus sesuai dengan keru-gian riil dan tata cara pembayarannya tergantung kesepakatan para pihak".

Grab menetapkan tarif ganti rugi sebesar Rp1000 untuk Grab Bike dan Rp3000 untuk Grab Car, Grab Car 6, Grab Car Plus dan Grab Taxi dengan ketentuan waktu pembatalan 5 menit setelah mendapatkan mitra pengemudi. Tarif tersebut berlaku secara mutlak sesuai ketentuan yang berlaku. Tidak ditentukan berdasarkan waktu, jarak, ataupun lainnya. Padahal, dalam setiap perjalanan, kondisi yang ditempuh mitra pengemudi tidak 
mungkin sama rata. Ditambah lokasi penjemputan yang jaraknya berbeda-beda dan juga waktu pembatalan yang tidak selalu 5 menit tepat.

Jika Grab mematok besaran tarif tetap seperti itu, maka tidak sesuai dengan ketentuan Fatwa DSN-MUI No. 43 di atas. Karena tarif yang diberikan tidak selalu sesuai dengan kerugian riil yang dialami.

6. "Besarnya ganti rugi ini tidak boleh dicantumkan dalam akad".

Besaran tarif pembatalan order atau tarif ganti rugi yang ditetapkan oleh Grab ini sudah diinformasikan kepada para pengguna Grab ketika kebijakan ini mulai berlaku yaitu sejak tanggal 17 Juni 2019. Seluruh pengguna Grab di Lampung dan Palembang akan mendapatkan pemberitahuan di aplikasi masing-masing seperti gambar di bawah ini :

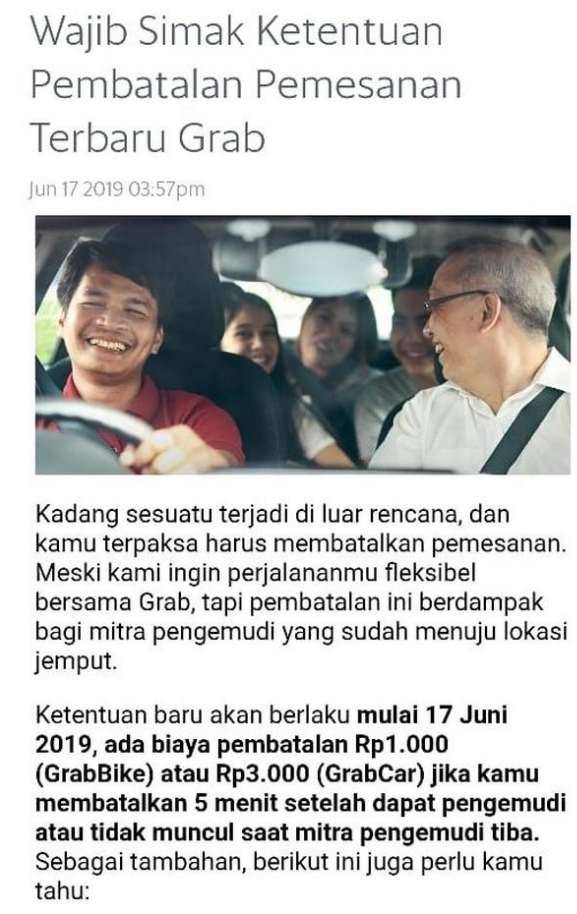

Artinya, Grab sudah menetapkan besaran tarif ganti rugi di awal akad. Maka dapat dikatakan kebijakan ini tidak sesuai dengan ketentuan Fatwa DSN-MUI No. 43 tahun 2004 yang menyebutkan bahwa tarif ganti rugi tidak boleh dicantumkan dalam akad, karena besarnya kerugian yang dialami tidak mungkin sama dan situasinya pun berbeda. Sehingga tarifnya harus diperhitungkan dengan jelas sesuai dengan kerugian yang dialami.

\section{Kesimpulan}

Kebijakan penerapan tarif pembatalan order yang dilakukan Grab di Lampung dan Palembang tersebut sesuai dengan ketentuan umum ganti rugi yang tercantum dalam Fatwa DSN-MUI No. 43 Tahun 2004. Namun jika ditinjau dari besaran tarif yang ditetapkan oleh Grab yaitu sebesar Rp1000 untuk Grab Bike dan Rp3000 untuk Grab Car yang mana telah disebutkan di awal transaksi, maka kebijakan tersebut tidak sesuai dengan Fatwa DSN-MUI No. 43 Tahun 2004 yang menyebutkan bahwa besaran ganti rugi tidak boleh disebutkan dalam akad. Alasannya karena besaran ganti rugi yang boleh dibebankan yaitu hanyalah kerugian riil yang dialami oleh pihak yang terlibat, sehingga hanya bisa dihitung secara jelas setelah kerugian tersebut terjadi, bukan di awal akad yang mana kerugian belum terjadi. Sehingga besaran ganti rugi dapat diperhitungkan secara jelas tanpa adanya spekulasi.

\section{Acknowledge}

Penulis mengucapkan terimakasih sebanyak-banyaknya atas seluruh pihak yang terlibat dalam penelitian ini. Kepada Allah SWT. karena atas rahmat dan ridho-Nya lah penelitian ini dapat 
terselesaikan. Kepada Ibu Eva Misfah Bayuni, S.E.I., M.E.Sy., dan juga Bapak Iwan Permana, S.Sy.,M.E.Sy., yang telah membantu dan membimbing penulis dalam melakukan penelitian, tidak lupa jajaran dosen dan staff Fakultas Syariah UNISBA yang banyak memberikan ilmu sehingga tercetuslah judul penelitian ini, dan juga kerabat yang senantiasa mendukung penulis.

\section{Daftar Pustaka}

[1] Adam, P. (2018). Fikih Muamalah Adabiyah (Anna (ed.); 1 ed.). PT. Refika Aditama.

[2] Dewan Syariah Nasional-MUI. (2004). Fatwa Dewan Syari'ah Nasional No. 43/DSNMUI/VIII/2004 tentang Ganti Rugi (Ta'widh).

[3] Santoso, H., \& Anik. (2015). Analisis Pembiayaan Ijarah pada Perbankan Syariah. Jurnal Ilmiah Ekonomi Islam, 01, 110.

[4] Website Grab Indonesia. (2021). https://www. Grab.com/id/

[5] (Adam, 2018; Dewan Syariah Nasional-MUI, 2004; Santoso \& Anik, 2015; Website Grab Indonesia, 2021) 